\title{
Water Supply and Demand Gap Analysis: A Case Study on Jessore Pourashava, Bangladesh
}

\author{
Hossain, K. M. Delowar ${ }^{1}$, M. A. Hakim ${ }^{1}$, Subrata Mondal ${ }^{2}$, Md. Abu Shamim Khan ${ }^{3}$ \\ and A. A. Seddique ${ }^{4}$
}

Dept. of Environmental Science \&Technology, Jessore University of Science \& Technology ${ }^{1}$ Dept. of Fisheries \& Marine Bioscience, Jessore University of Science \& Technology ${ }^{2}$

Senior Chemist, Asia Arsenic Network, Jessore Office ${ }^{3}$

Dept. of Petroleum \& Mining Engineering, Jessore University of Science \& Technology, Jessore, Bangladesh ${ }^{4}$

Corresponding author: subratajstu1975@gmail.com

\begin{abstract}
Jessore district is rapidly growing and a densely populated town of south western part of Bangladesh. Due to rapid urbanization and population growth, supply water demand is increasing day by day in Jessore pourashava areas. Thus, this study was carried out to understand the existing water supply and its demand. The study was conducted among 80 families, where total family members were 770. Reconnaissance survey and sampling unit methodology was used based on questionnaire for data collection followed by data interpretation and data analysis. Primary information was collected through questionnaire survey conducted with person to person from September to November, 2012. From each 20 identical sampling points, 4 samples were collected randomly. This study revealed that Jessore pourashava has per capita water demand is nearly 250 L/day, but pourashava supply about 72 L/capita/day, which is not enough for them. Thus, they meet their demand from their own sources. There are some other associated problems with water supply such as time of water supply, impurities in supplied water, low water pressure etc. About only 50 percent consumers are satisfied to pourashava water supply. Pourashava may be able to minimize this supply and demand gaps; and increase consumer satisfaction by installing more pumps which will withdraw more water for supply in pourashava areas. Monitoring and reduction of wastage of supply need to be addressed by increasing manpower of pourashava.
\end{abstract}

Key words: Water supply, Jessore pourashava, consumer satisfaction, demand gap

\section{Introduction}

The worldwide water supply is increasing day by day and it is not sufficient against their demand. At present only 0.08 per cent of everyone's fresh drinking water is exploited by mankind in ever increasing demand for sanitation, drinking, manufacturing, leisure and agriculture (NEST, 1991). This is due to growth of society, industrialization, pollution of water resources, and inefficient use and supplies of water. According to World Health Organization, 75 liters of drinking water per day is necessary to be able to prevent household disease and also 50 liters a day key for basic parent's sanitation (Abaje et al., 2009). In an urban area, uses an average of 250 liters/day (Basak, 2003), but individual consumption varies widely around the globe (Abaje et al., 2009). To meet future demand for water supply and sanitation services with reliable and safe water supply system, the management capacity of the urban utilities should continue to improve (Data Book, 2006-07). In Bangladesh, the water supply coverage has been increasing both in the urban and rural areas since the 80 's. However, almost 88 percent of water is withdrawn for irrigation, livestock while only 10 percent and two percent use it for household and industry, respectively (FAO, 2010). To attain the supply http://www.journalbinet.com/ 
coverage levels at 100 percent by 2010 , many programs have been initiated which deal with the massive task of rehabilitation, improvement and extension of the city's water supply systems (National Water Management Plan, 2001). Urban drinking water systems/utilities are usually facing heavy challenges of supplying safe water and sanitation services towards the sharply increasing population in the towns (Ayoade and Oyebande, 1983). Jessore is the first pourashava in our country and 3rd number pourashava of the subcontinent. Jessore pourashava is rapidly growing and densely populated, which has an area of $14.72^{2} \mathrm{~km}$. This is the greater district under the Khulna division that is located south west of Bangladesh with a population of 286163 (BBS, 2011). This lies between $21^{\circ} 45^{\prime}$ to $23^{\circ} 45^{\prime}$ north latitude and $89^{\circ} 15^{\prime}$ to $89^{\circ} 55^{\prime}$ east longitudes (Banglapedia, 2006). Water supply of this pourashava has been established in 1918. It provides water at 72 liter per capita per person to 68.0 percent of the population in its service area for an average of nine hours per day. The people are getting water supply through pipes. The water supply does not meet water requirement to customer satisfaction. Apart from inadequate water supply, problems related to water supply system might be existing in studied areas. The goals of the study were to understand the existing water supply and its demand, problems of water supply system and to analyze demand gap between water supply and consumer expectation.

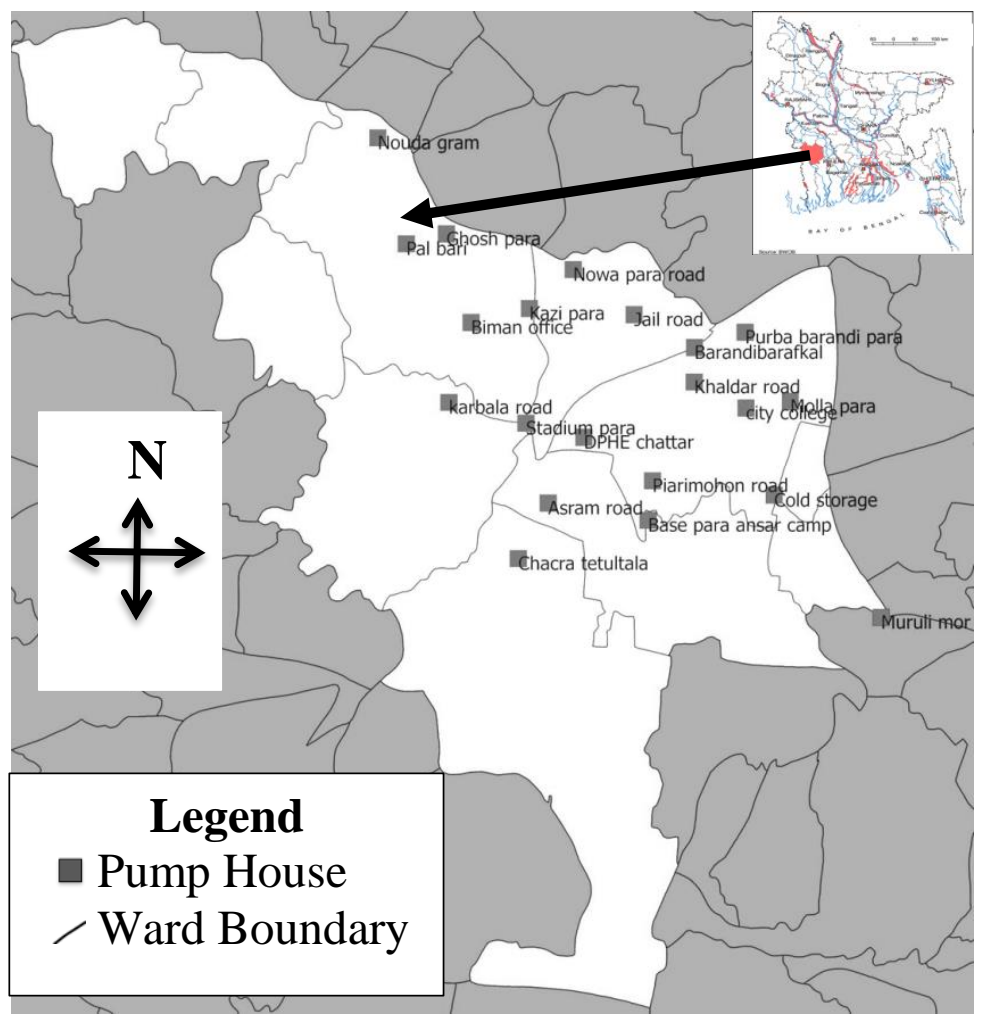

Figure 1. Location map of the study area based on GPS reading.

\section{Materials and Method}

This research was survey based where primary information came from the consumers, those use supplied water from Jessore pourashava. A reconnaissance survey was taken by focus group discussion for preliminary investigation of the study area and to decide on optimum sampling points and study units. After that a research design was formulated based on that reconnaissance survey where personal interviews were collected through questionnaire (water consumption source, use of water, consumer water demand, consumer satisfaction). For collecting information, this study area was divided into 20 identical points depending on water supply pump. These pumps were indicated through GPS reading. From each sampling points more than 4 people interview were taken. 
Secondary information was collected from the pourashava office, books and journals. Even personal comments were taken from the Water Superintendent of Jessore pourashava.

\section{Results and Discussion}

\section{Status of water supply in Jessore Pourashava}

Production capacity of water pump at Jessore pourashava: The highest productive pump was Chachra Tatultala and maximum productivity was $130 \mathrm{~m}^{3} / \mathrm{d}$. The lowest capacity pump was inside pourashava office, Biman office, Ghosh para, Piarymohon road, Chopder para and Molla para, with maximum capacity was $100 \mathrm{~m}^{3} / \mathrm{d}$ and the total production was about $2072 \mathrm{~m}^{3} / \mathrm{d}$. During this survey, the highest productive pump was obtained at Chachra Tatultala and its maximum productivity was $122 \mathrm{~m}^{3} / \mathrm{d}$. Similarly, the lowest productive pumps were at Jail road, Benapole road and Chopdar para, with productive capacity were about $22 \mathrm{~m}^{3} / \mathrm{d}$ (Table 1). At present, total production is $1529 \mathrm{~m}^{3} / \mathrm{d}$ which accounts the entire active pump houses. But according to Data Book 2006-07, Jessore pourashava provides water at $72 \mathrm{~L} /$ capita/day to its consumers for an average of nine hours per day. Survey data represent that pourashava people meet about $180 \mathrm{~L} /$ capita/day from their own sources. This is the main demand gap between water supply and water consumption in Jessore pourashava.

Table1. Status of production pumps at Jessore pourashava with its GPS location

\begin{tabular}{c|l|c|c|c|c|c}
\hline Well & \multicolumn{1}{c}{ Location } & Ward & \multicolumn{2}{c|}{ GPS Reading } & \multicolumn{2}{c}{ Capacity $\left(\mathrm{m}^{3} / \mathrm{d}\right)$} \\
\cline { 4 - 7 } No. & & No. & GPS (N) & GPS $(\mathrm{E})$ & At installed & At present \\
\hline 01 & Inside pourashava & 05 & $23^{\circ} 10.123$ & $089^{\circ} 12.154$ & 100 & 68 \\
02 & Biman office & 05 & $23^{\circ} 10.279$ & $089^{\circ} 12.002$ & 100 & 54 \\
03 & Palbari & 05 & $23^{\circ} 10.669$ & $089^{\circ} 11.681$ & 120 & 90 \\
04 & Ghosh para & 03 & $23^{\circ} 10.718$ & $089^{\circ} 11.880$ & 100 & 54 \\
05 & Kazipara & 04 & $23^{\circ} 10.348$ & $089^{\circ} 12.291$ & 110 & 90 \\
06 & Jail road & 03 & $23^{\circ} 10.318$ & $089^{\circ} 12.810$ & 110 & 22 \\
07 & Stadium para & 05 & $23^{\circ} 09.780$ & $089^{\circ} 12.274$ & 120 & 113 \\
08 & DPHE Chattar & 07 & $23^{\circ} 09.710$ & $089^{\circ} 12.561$ & 110 & 104 \\
09 & Benapole road & 05 & $23^{\circ} 09.005$ & $089^{\circ} 12.126$ & 100 & 22 \\
10 & Chacra tetultala & 06 & $23^{\circ} 09.109$ & $089^{\circ} 12.236$ & 130 & 122 \\
11 & Asrom road & 08 & $23^{\circ} 09.384$ & $089^{\circ} 12.384$ & 110 & 104 \\
12 & Piary mohon road & 02 & $23^{\circ} 09.495$ & $089^{\circ} 12.901$ & 100 & 90 \\
13 & Chopder para & 07 & $23^{\circ} 09.277$ & $089^{\circ} 12.860$ & 100 & 22 \\
14 & Bok-chor hustala & 09 & $23^{\circ} 09.423$ & $089^{\circ} 13.504$ & 110 & 104 \\
15 & City college & 01 & $23^{\circ} 09.855$ & $089^{\circ} 13.364$ & 0 & 0 \\
16 & Molla para & 01 & $23^{\circ} 09.888$ & $089^{\circ} 13.584$ & 100 & 81 \\
17 & Purbo barandipara & 01 & $23^{\circ} 10.231$ & $089^{\circ} 13.360$ & 122 & 118 \\
18 & Barandi Borofkal & 04 & $23^{\circ} 10.155$ & $089^{\circ} 13.109$ & 120 & 113 \\
19 & Khaldhar road & 04 & $23^{\circ} 09.984$ & $089^{\circ} 13.108$ & 100 & 54 \\
20 & Karbala road & 05 & $23^{\circ} 09.883$ & $089^{\circ} 11.892$ & 110 & 104 \\
\hline
\end{tabular}

Percentage of tubewell: In Jessore pourashava, 90\% households have their own tubewells. Whereas about $10 \%$ household have no tubewell and they meet their water demand from supply or other sources (Figure 1). 


\section{Status of Tubewell in Jessore}

Pourashava

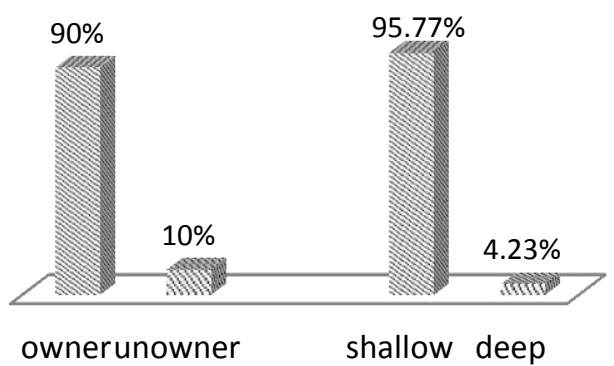

Figure 1. Status of tubewell at study area depending on ownership and depth.

\section{Percentage of household who use water and stored it.}

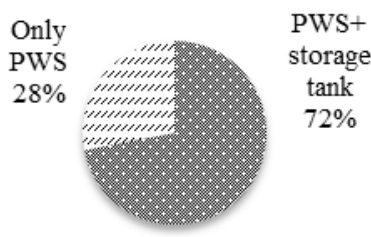

Figure 3. Percentage of people who use supply water and have storage tank.

\section{Status of PWS Connection}

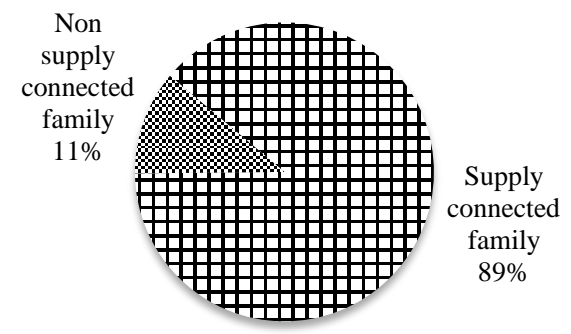

Figure 2. Status of pourashava water supply (PWS) connection.

\section{Consumer satisfaction by using pourashava water supply.}

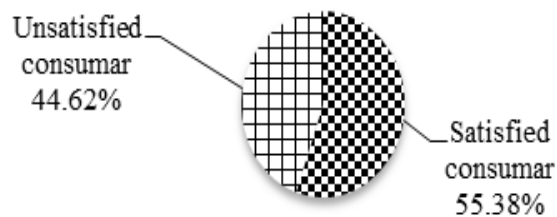

Figure 4. Graphical representation of percentage of consumer satisfaction by using pourashava water supply.

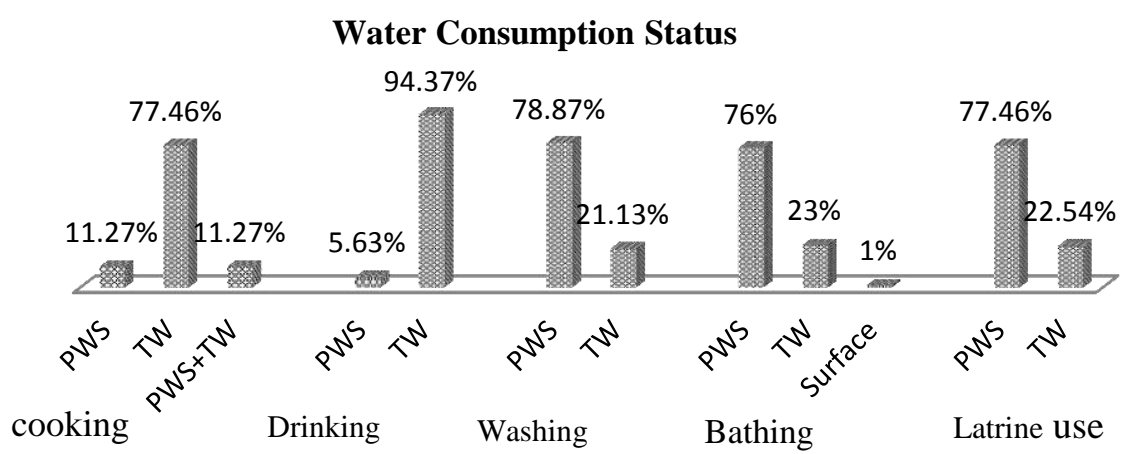

Figure 5. Status of water consumption pattern at the study area

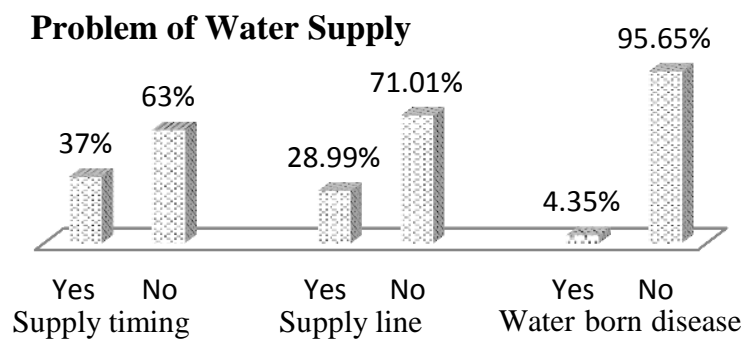

Figure 6. Status of problems with water supply system

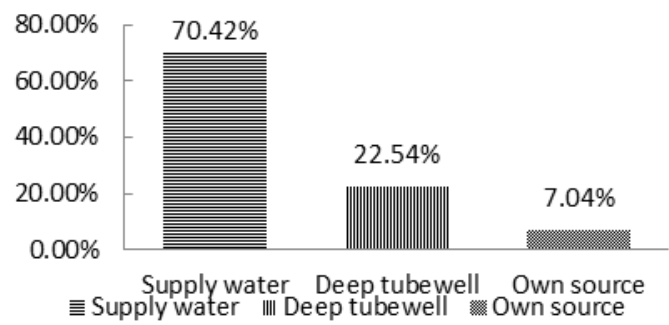

Figure 7. Percentage of householders who depends on alternative sources during water crisis period. 
Depth of tubewell: In Jessore pourashava, there are nearly 95\% tubewells which are shallow and 6\% tubewells were deep (Figure 1). Jessore town is beside Bhairab River and it is southward part of the Bangladesh, where shallow aquifers are available and people get layer within $110 \mathrm{ft}$. As a result, the percentage of shallow tubewell is higher than deep tubewell in those places.

Pourashava water supply (PWS) connection status: Survey data shows that in Jessore pourashava about $89 \%$ household have connection of pourashava water supply and about $11 \%$ household in the pourashava have no water supply connection from pourashava (Figure 2).

\section{Water consumption pattern}

Water use and storage by the pourashava people: In Jessore pourashava, there are about $28 \%$ households who only depend on pourashava water supply. They have no own storage water tank and they use big type of bucket to store supplied water for use, when supply water is not available e.g. night time. On the other hand, about $72 \%$ households have pourashava water supply line and own storage tank that filled up by own motor (small electric based pump used for filling up small size tanks) (Figure 3).

Water used for cooking: There are nearly $11.27 \%$ household used supply water for cooking, similarly $11.27 \%$ household used supply and tubewell water. The rest $77.46 \%$ household purely used tubewell water for cooking purpose (Figure 5).

Water used for drinking: About 5.63\% households in the pourashava use supply water for their drinking purposes; on the other hand nearly $94.37 \%$ households use tubewell water for their drinking purposes (Figure 4).

Water used for household washing: This study shows that about $21.13 \%$ households use tubewell water for their washing purposes. Other $78.87 \%$ households use supply water for washing (Figure 4).

Water used for bathing: About $1 \%$ households use surface water for bathing which is negligible, about $23 \%$ households use tubewell water for bathing. The rest $76 \%$ households use supply water for bathing purpose (Figure 4).

Water used for latrine purpose: In this study, nearly $22.54 \%$ households who use tubewell water for latrine purpose. On the other hand, nearly $77.46 \%$ households use supply water for latrine purpose (Figure 4).

\section{Public satisfaction}

Consumer satisfaction: In the Jessore pourashava, about $55.38 \%$ households are satisfied by pourashava water supply but about $44.62 \%$ household are not satisfied by pourashava water supply (Figure 4). There are some contaminants in supply water such as Fe, Mn, Bacteria. Sometimes, it create some kind of odors as well. Concentration of Fe $(0.12-6.21 \mathrm{mg} / \mathrm{l})$ and $\mathrm{Mn}(0.12-0.80 \mathrm{mg} / \mathrm{l})$ are higher than the standard value of Bangladesh $(\mathrm{Fe}, 0.3-1.0 \mathrm{mg} / \mathrm{l}$ and $\mathrm{Mn}, 0.10 \mathrm{mg} / \mathrm{l})$ and $\mathrm{WHO}(\mathrm{Fe}, 0.3$ $\mathrm{mg} / \mathrm{l}$ and Mn, $0.10 \mathrm{mg} / \mathrm{l}$ ) (Shaibur et al., 2012).

\section{Problem associated with water supply}

Problem due to supply timing: There are about $63 \%$ households who do not face problem due to supply timing because they have own source of water as tubewell, storage tank etc. by which they meet their water demand. About $37 \%$ households are being faced by various problems due to supply timing of water (Figure 6). 
Problem faced by supply line: From the survey data, it is evident that about $71.01 \%$ households of pourashava do not face any problem of pourashava water supply lines in recent years. On the other hand, there are about $28.99 \%$ households faced problem in the water supply lines as leakage or blockage (Figure 6). At the last year at 2012 there are nearly 152 to 180 number leakages is detected around the pourashava area which were repaired.

Diseases due to use of supply water (SW): There are few household who faced water borne diseases by using supplied water which are mainly skin diseases and their percentage were nearly $4.35 \%$. There is no Arsenic contamination in the supply water except some parts of 4 and 5 number wards (Shaibur et al., 2012). But high Mn (over $0.10 \mathrm{mg} / \mathrm{l}$ ) concentration may create chronic health effects as cancer, birth defects, damage of organ, nervous system disorder and immune system damage (Sobsey and Pfaender, 2002).

Alternative dependable sources at water crisis period: Every year water crisis take place at summer. Pourashava peoples mainly depend on the three sources such as supply water, deep tubewell, and own sources. This study represents that nearly $7.04 \%$ householder depend on own source. About $22.54 \%$ householders depend on other deep tubewell. The rest nearly $70.42 \%$ householders depend on the supply water at summer for getting water (Figure 7). In the southwest part of Bangladesh Shallow aquifer lies more than $50 \mathrm{~m}$ from the surface (Ahmed \& Rahman, 2003) but it may draw down from 1 to $8 \mathrm{~m}$ at dry season (BADC, 2012). Due to draw down water table most of shallow tubewell cannot get recharge enough water so water crisis is arising. During this time, supply water is available for this reason majority of households depend on pourashava supply water.

\section{Case Study Remarks}

The study revealed that Jessore pourashava water supply cannot fulfill consumer demand for water. Because, there are some limitations which are electricity problem, shortage of enough pumps houses and manpower shortage. Some noted associated problem with water supply are supply line problem, diseases due to use of supply water, impurities in supply water, bacterial contamination, supply timing etc. With increase population the water demand is increasing. To meet their daily water demand most of the households were installed tubewell in their house. By installing more and powerful water supply pump and taking proper monitoring, investigation, reporting, and management can ensure maximum water supply for consumers in Jessore pourashova.

\section{Acknowledgement}

We are grateful to the staff of Jessore pourashava and Special thanks to Mr. Mahfuzur Rahman, Lecturer, Dept. of Environmental Science and Technology, Jessore University of Science and Technology, Jessore - 7408, Bangladesh, and Md. Maruf Hossain, Asia Arsenic Network, Jessore. 


\section{Reference}

Abaje, I. B., Ati, O. F. \& Ishaya, S. (2009). Nature of potable water supply and demand in Jema'a local government area of Kaduna State, Nigeria. Research Journal of Environmental and Earth Sciences 1(1), 16-21.

Ahmed, M. F. \& Rahman, M. M. (2003). Water Supply \& Sanitation: rural and low income urban communities, ITN-Bangladesh center for water supply and waste management, Civil Engineering Building ( $3^{\text {rd }}$ floor), BUET, Dhaka-1000, Bangladesh.

Ayoade, J. O. \& Oyebande, B. L. (1983). Water Resources. In: A Geography of Nigerian Development, Eds, Oguntoyinbo, J. S., O. O., Areola and M., Filani, Heinemann. Educational Books (Nigeria) Limited, Ibadan.

Banglapedia (2006). National Encyclopedia of Bangladesh. Asiatic society of Bangladesh. 5 old Secretariat Road Nimtali, Dhaka-1000.

Bangladesh Agriculture Development Corporation (BADC), 2012. Survey and monitoring project report. Jessore, Bangladesh.

Basak, N. N. (2003). Environmental Engineering, published by Tala McGraw Hill Education Private Limited, 7 west Patel Nagar, New Delhi 110 008, typist in Times at the composers, 260, C, A , Apt Paschim Vihar, New Delhi 110063 and printed at India binding house, Nodia 201301.

BBS (2011). Statistical pocketbook of Bangladesh. Bangladesh Bureau of Statistics. Statistics Division, Ministry of Planning. Government of the People Republic of Bangladesh.

Data Book (2006-07). Benchmarking for Improving Water Supply Delivery in Bangladesh, Water Utilities.

FAO (Food and Agricultural Organization) (2010). Aqua Stat. Online available at: http://www.fao.org/nr/water/aquastat/countries/Bangladesh.

National Water Management Plan (2001). Water Resources Planning Organization (WARPO). Main Report Vol-II. Ministry of Water Resources, Government of Bangladesh.

NEST (1991). Nigerian Environmental Study/Action Team, Nigeria's Threatened Environment: A National Profile, Nigerian Environmental Study/Action Team (NEST), A NEST publication, Ibadan.

Shaibur, M. R. Hassan, M. N. A, Sohel, M. R. \& Khan, M. A. S. (2012). Assessment of Supplied Water Quality at Jessore Municipality (Pourashava), Bangladesh. Bangladesh Journal of Environmental Research, 10, 69-87.

Sobsey, M. D. \& Pfaender, A. (2002). Managing water in the home: accelerated heath gains from improved water supply. WHO, Geneva, Switzerland.

\section{Citation for this article (APA Style):}

Hossain, K. M. Delowar, Hakim, M. A., Mondal, S., Khan, M. A. S., \& Seddique, A. A. (2014). Water Supply and Demand Gap Analysis: A Case Study on Jessore Pourashava, Bangladesh. Journal of Bioscience and Agriculture Research, 02(01), 08-14. Retrieved October 07, 2014, from http://www.journalbinet.com/current-issue-jbar-1.html. 